\title{
KOMUNIKASI INTERPERSONAL TENAGA PENDIDIKTERHADAP KEBERHASILAN BELAJAR SISWA PADA MIS ASSALAM MARTAPURA DAN MIN SUNGAI SIPAI KABUPATEN BANJAR
}

\author{
M. Ropiani \\ Email: ropiani88@gmail.com \\ Dosen Fakultas Tarbiyah STAI Darussalam Martapura \\ Jalan Perwira Tanjung Rema No. 01 Martapura Kabupaten Banjar
}

\begin{abstract}
The research uses quantitative approach method; the data is used in general in the form of numbers calculated through statistical test with descriptive correlational analytic specification. This research describes systematically, factually, and accurately, also attempts to provide an overview of what it relates to later research, to analyze to find the solution of the problems encountered. The results of observations conducted on two Madrasah Ibtidaiyah in Kabupaten Banjar, namely Madarasah Ibtidaiyah Assalam Martapura and Madrasah Ibtidaiyah Negeri Sipai River, where the two Madrasah Ibtidaiyah is Madrasah Ibtidaiyah Assalam Martapuran is a private school under the auspices of the Ministry of Religious Affairs who was also built from Madrasah Ibtidaiyah Negeri Sungai Sipai, both schools are often found factors that affect this learning include teaching methods, educational teacher curriculum with students, student relationships with students, disciplines, lessons, facilities and time, learning standards, the state of the building, learning methods, and tasks home. Teaching and learning is a core behavior in the educational process in which students and teachers interact. The interaction of teaching and learning is supported by several other factors in education, among others: educational objectives, educators, students, nature and educational facilities, teaching methods, subject matter and environment.
\end{abstract}

Keywords: Communication, Interaction, successful

\section{PENDAHULUAN}

Peranan pendidikan dalam kehidupan manus ia sangat besar sekali dalam kehidupan individu, keluarga, suku, bangsa maupun negara dan maju mundurnya suatu bangsa tergantung pada maju mundurnya pendidikan yang mereka laksanakan.

Pendidikan bertujuan tidak hanya untuk mentransfer kebudayaan dari satu generasi kegenerasi berikutnya akan tetapi pendidikan mampu membantu watak dan kepribadian manusia seutuhnya, baik jasmani maupun rohani sehingga nantinya dapat membawa masyarakat, bangsa dan negara maju. ${ }^{1} \mathrm{Hal}$ ini juga selaras dengan tujuan pendidikan nasional yang telah tercantum dalam Undang-Undang Pendidikan Republik Indonesia Nomor 20 Tahun 2003 tentang Sistem Pendidikan nasional dalam Bab II pasal 3 yang berbunyi: ${ }^{2}$ Pendidikan nasional berfungsi mengembangkan kemampuan dan membentuk watak serta peradaban bangsa yang bermartabat mencerdaskan kehidupan bangsa, bertujuan untuk berkembang potensi peserta didik agar menjadi manusia yang beriman dan bertakwa

\footnotetext{
${ }^{1}$ Sardiman AM, Interaksi dan Moivasi Belajar Pengajar. Jakarta: Rineka Cipta

${ }^{2}$ Samana, 1999. Profesionalisme Ketenaga Pendidikan. Yogyakarta: Kanisius. Undang-Undang Pendidikan Republik Indonesia Nomor 20 Tahun 2003 tentang Sistem Pendidikan nasional dalam Bab II pasal 3
} 
kepada Tuhan Yang Maha Esa, berakhlak mulia, sehat, berilmu, cakap, kreatif, mandiri dan menjadi warga Negara demokratis serta bertanggungjawab. (Undang-Undang RI No. 20 Tahun 2003. Tentang Pendidikan Nasional, 2003: 10)

Proses belajar mengajar akan senantiasa merupakan proses kegiatan interaksi antara dua unsur manusiawi di mana siswa sebagai pihak yang belajar dan guru sebagai pihak yang mengajar. Proses itu sendiri merupakan mata rantai yang menghubungkan antara guru dan siswa sehingga terbina komunikasi yang memiliki tujuan yaitu tujuan pembelajaran.

Guru sebagai tenaga profesional di bidang pendidikan, disamping memahami hal-hal yang bersifat filosofis dan konseptual, juga harus mengetahui dan melaksanakan hal-hal yang bersifat teknis. Hal-hal yang bersifat teknis ini, terutama kegiatan mengelola dan melaksanakan interaksi belajar mengajar.

Dalam proses pendidikan sering kita jumpai kegagalan-kegagalan,hal ini biasanya dikarenakan lemahnya sistem komunikasi. Untuk itu, pendidik perlu mengembangkan pola komunikasi efektif dalam proses belajar mengajar. Komunikasi pendidikan yang penulis maksudkan disini adalah hubungan atau interaksi antara pendidik dengan peserta didik pada saat proses belajar mengajar berlangsung, atau dengan istilah lain yaitu hubungan aktif antara pendidik dengan peserta didik.

Komunikasi adalah Proses penyampaian pesan dari komunikator kepada komunikan yang dapat menimbulkan efek tertentu. ${ }^{3}$ Guru adalah seorang anggota masyarakat yang berkompeten dan memperoleh kepercayaan dari masyarakat dan atau pemerintah untuk melaksanakan tugas, fungsi dan peranannya, yakni mengajar, mendidik dan membimbing serta menuntut siswa dalam belajar atau dengan kata lain guru adalah salah satu komponen manusiawi dalam usaha pembentukan sumber daya manusia dan sebagainya. Sedangkan Siswa adalah Setiap orang yang menerima pengaruh dari seseorang atau sekelompok orang yang menjalankan kegiatan pendidikan.

Keduanya baik guru maupun siswa merupakan unsur penting dalam proses pembelajaran, karena merekalah yang melakukan proses pembelajaran. Proses pembelajaran tidak akan terjadi jika tidak ada guru atau pun siswa.

Dengan melihat pada pengertian bahwa pendidikan adalah usaha sadar dari guru yang bertujuan untuk mengembangkan kualitas siswa, terkandung suatu makna bahwa proses yang dinamakan pendidikan itu tidak akan pernah berlangsung apabila tidak hadir guru dan siswa dalam rangkaian kegiatan belajar mengajar. Sehingga bisa dikatakan bahwa guru dan siswa merupakan pilar utama terselenggaranya aktivitas pendidikan.

Tenaga pendidik yang kurang berinteraksi dengan siswa secara akrab, menyebabkan proses pembelajaran kurang lancar dan siswa merasa jauh dari tenaga pendidik maka segan berpartisipasi secara aktif dalam belajar. Komunikasi interpersonal tenaga pendidik merupakan salah satu bentuk relasi tenaga pendidik dan siswa yang merupakan faktor yang mempengaruhi belajar. Belajar mengajar merupakan perilaku inti dalam proses pendidikan dimana anak didik dan pendidik berinteraksi. Interaksi belajar mengajar ditunjang oleh beberapa faktor lain dalam pendidikan antara lain: tujuan pendidikan, pendidik, anak didik, alam dan fasilitas pendidikan, metode mengajar, materi pelajaran dan lingkungan. ${ }^{4}$

\footnotetext{
${ }^{3}$ Ngalimun, 2017. Ilmu Komunikasi Sebuah Pengantar Praktis. Banjarmasin: Pustaka Banua

${ }^{4}$ Samana, 1999. Profesionalisme Ketenaga Pendidikan. Yogyakarta: Kanisius.
} 
Belajar mengajar itu perlu juga adanya stimuli. Yang dimaksud stimuli belajar disini yaitu segala hal di luar individu yang merangsang individu untuk mengadakan reaksi atau perbuatan belajar. Stimuli dalam hal ini mencakup material, penugasan serta suasana lingkungan eksternal yang harus diterima atau dipelajari si pelajar. Faktor-faktor personal secara langsung mempengaruhi kecermatan persepsi, bukan proses itu sendiri. Persepsi interpersonal besar pengaruhnya bukan saja pada komunikasi interpersonal, tetapi juga pada hubungan interpersonal. Pengalaman juga mempengaruhi kecermatan persepsi. Pengalaman tidak selalu lewat belajar formal. Pengalaman bertambahnya melalui rangkaian peristiwa yang pernah dihadapi. $^{5}$

Dalam hasil pengamatan yang di lakukan pada dua Madrasah Ibtidaiyah di Kabupaten Banjar, yakni Madarasah Ibtidaiyah Assalam Martapura dan Madrasah Ibtidaiyah Negeri Sungai Sipai, dimana dari dua Madrasah Ibtidaiyah tersebut adalah Madrasah Ibtidaiyah Assalam Martapuran merupakan sekolah swasta di bawah naungan Kemenag yang jua binaan dari Madrasah Ibtidaiyah Negeri Sungai Sipai, pada kedua sekolah tersebut sering di jumpai bahwa faktor yang mempengaruhi belajar ini meliputi metode mengajar, kurikulum relasi tenaga pendidik dengan siswa, relasi siswa dengan siswa, disiplin, pelajaran, falisilitas dan waktu, standar pelajaran, keadaan gedung, metode belajar dan tugas rumah. Belajar mengajar merupakan perilaku inti dalam proses pendidikan dimana anak didik dan pendidik berinteraksi. Interaksi belajar mengajar ditunjang oleh beberapa faktor lain dalam pendidikan antara lain: tujuan pendidikan, pendidik, anak didik, alam dan fasilitas pendidikan, metode mengajar, materi pelajaran dan lingkungan.

Ketika tenaga pendidik menghadapi murid- muridnya yang bermacam-macam, ia akan mengelompokkan mereka pada konsep tertentu yakni cerdas, bodoh, jelek, rajin, malas. Penggunaan stimuli ini menyederhanakan stimuli yang diterima. Keberhasilan komunikasi interpersonal bergantung pada konsep diri (positif/ negatif). ${ }^{6}$

Pengetahuan tentang diri akan meningkatkan komunikasi dan pada saat yang sama, berkomunikasi dengan orang lain meningkatkan pengetahuan tentang diri seseorang. Dengan membuka diri, konsep diri menjadi lebih dekat pada kenyataan.

Bila konsep diri, sesuai dengan pengalaman seseorang, orang akan lebih terbuka untuk menerima pengalaman-pengalaman dan gagasan-gagasan baru, lebih cenderung menghindari sikap defisit dan lebih cermat memandang diri kita dan orang lain. Keinginan untuk menutup diri selain karena konsep diri yang negatif timbul dari kurangnya kepercayaan kepada kemampuan sendiri. Orang yang tidak menyenangi dirinya merasa bahwa dirinya tidak akan mampu mengatasi masalah persoalan.

Orang yang kurang percaya diri akan cenderung sedapat mungkin menghindari situasi komunikasi. Seseorang akan menyukai orang yang memberi ganjaran kepadanya. Ganjaran itu berupa bantuan, dorongan moril, pujian/hal-hal lain yang meningkatkan harga dirinya. Demikian halnya peserta didik mempunyai wali kelas yang penuh perhatian, sering memberi nasehat, mengajak berkomunikasi maka peserta didik tersebut akan merasa senang dan diperhatikan. Hal ini akan membuat peserta didik terpacu untuk belajar dan akan merasa malu jika prestasinya jelek karena akan mendapat teguran dari wali kelas.

\footnotetext{
${ }^{5}$ Piet A. Sahertian, 2010. Profil Pendidik Profesional. Yogyakarta: Andi Offset

${ }^{6}$ Suranto, 2010. Komunikasi Sosial Budaya. Yogyakarta: Graha ilmu
} 
Pendidikan di sekolah tidak terbatas pada saat terjadi secara informal saja tetapi juga penting pendidikan secara formal. Tetapi pendidikan di sekolah juga mencakup pergaulanpergaulan di luar kelas antara peserta didik dengan peserta didik dengan yang lain dan peserta didik dengan tenaga pendidik termasuk kepala sekolah diluar kelas atau tidak dalam kegiatan interaksi belajar mengajar.

Pada saat ini terbuka kesempatan tenaga pendidik untuk menciptakan pergaulan yang mendidik bagi peserta didiknya. Untuk itu komunikasi interpersonal peserta didik sebagai alat transfer ilmu sangat penting artinya. Bahkan sangat besar peranannya dalam menentukan keberhasilan pendidikan yang bersangkutan. Sering dikatakan bahwa tinggi rendahnya suatu capaian mutu pendidikan dipengaruhi pula oleh faktor komunikasi antara pengajar atau pendidik dengan peserta didik diantaranya komunikasi interpersonal. ${ }^{7}$ Dengan adanya interaksi positif antara peserta didik dengan tenaga pendidik melalui komunikasi interpersonal yang baik dapat menyelesaikan perbedaan-perbedaan tersebut sehingga semangat belajar peserta didik akan timbul karena termotivasi oleh tenaga pendidiknya.

\section{LANDASAN TEORI}

\section{A. Pengertian komunikasi}

Istilah komunikasi dalam bahasa Inggris yakni communication. ${ }^{8}$ Pada dasarnya, secara etimologis kata komunikasi berasal dari bahasa Latin yaitu communication yang bersumber pada kata communis berarti milik bersama atau membagi merupakan suatu proses yang bertujuan untuk membangun pengertian dan kebersamaan sedangkan secara terminologis, kata komunikasi merujuk pada proses penyampaian suatu pernyataan oleh pihak satu kepada pihak lain. Pengertian Komunikasi merupakan suatu proses ketika seseorang dengan orang lain saling menyampaikan informasi dari satu pihak ke pihak lain/banyak pihak agar dapat terhubung dengan lingkungan sekitarnya.

Menurut Handoko dalam Rakhmat Kriyantono (2010) mengatakan bahwa komunikasi adalah proses pemindahan pengertian dalam bentuk gagasan atau informasi dari seseorang ke orang lain, yang melibatkan lebih dari sekedar kata-kata yang digunakan dalam percakapan, tetapi juga ekspresi wajah, intonasi, titik putus lokal dan sebagainya. ${ }^{9}$ Dan perpindahan efektif memerlukan tidak hanya tranmisi data, tetapi bahwa seseorang mengirim berita dan menerimanya sangat tergantung pada keterampilan-keterampilan tertentu (membaca, menulis, mendengar, berbicara, dan lain-lain).

Hovland, Janis dan Kelly dalam Wood Julia T (2010) mendifinisikan komunikasi sebagai: "the process by chich and individual (the communicator) transmits stimuli (usually verbal) to modify the behavior of other individuals (the audience)". Sedangkan Dance mengartikan komunikasi dalam kerangka psikologi behaviorisme sebagai usaha menimbulkan respon melalui lambang-lambang verbal tersebut bertindak sebagai stimuli. ${ }^{10}$

Komunikasi adalah proses pengiriman atau penyampaian berita atau informasi dari satu pihak kepihak lain dalam usaha untuk mendapatkan saling pengertian. Aktivitas komunikasi dalam sebuah institusi senantiasa dengan tujuan pencapaian baik dalam kelompok

\footnotetext{
${ }^{7}$ Suciati, 2015. Komunikasi Interpersonal. Yogyakarta Buku litera

${ }^{8}$ Wood, Julia T. 2010. Interpersonal Communication: Everyday Encounter. Australia: Wadsworth

${ }^{9}$ Rachmat Kriyantono, 2010. Teknik Praktis Komunikasi. Jakarta: Kencana Prenada

${ }^{10}$ Wood, Julia T. 2010. Interpersonal Communication: Everyday Encounter. Australia: Wadsworth
} 
maupun dalam masyarakat. Budaya komunikasi dalam konteks komunikasi organisasi harus dilihat dari berbagai sisi, misal komunikasi dari atasan kepada bawahan ataupun komuniasi antar personal, juga dari bawahan kepada atasan dengan polanya masing-masing. Untuk melakukan komunikasi dengan baik kita mengetahui situasi dan kondisi serta karakteristik lawan bicara kita, sebagaimana yang kita tahu, bahwa setiap manusia itu seperti sebuah radar yang dilingkupi lingkungan. Manusia bias menjadi sangat sensitive pada bahasa tubuh, ekspresi wajah, postur, gerakan, intonasi suara dan lainya.

Menurut Mulyana (2009: 12) bahwa komunikasi didefinisikan sebagai apa yang terjadi bila makna diberikan kepada suatu prilaku. ${ }^{11}$ Bila seseorang memperhatikan perilaku kita dan memberikan makna, komunikasi telah terjadi terlepas dari apakah kita menyadari perilaku kita atau tidak dan mengejanya atau baik. Bila kita memikirkan hal ini, kita harus menyadari bahwa tidak mungkin bagi kita untuk tidak berperilaku. Setiap perilaku memiliki potensi komunikasi, maka tidaklah mungkin bagi kita untuk tidak berkomunikasi; dengan kata lain, kita tidak dapat berkomunikasi.

Komunikasi yang efektif dapat terjalin dengan baik apabila kedua belah pihak saling mengakui kekurangan dan kelebihan orang lain serta mengerti kelemahan orang lain. ${ }^{12}$ Oleh karena itu, segala hambatan dapat diatasi dengan baik, segala macam ego dalam diri kita dapat dihilangkan sehingga hanya ada keinginan untuk bisa saling memahami orang lain seutuhnya tanpa ada pamrih yang lain. Setelah itu, rasa saling percaya antar individu dalam suatu lingkungan akan tercipta dengan baik sehingga segala hambatan/tantangan dapat diatasi dan terjalin kerjasama yang baik. Sebab setiap individu mempunyai semangat yang sama dalam membangun dan membantu orang lain. Dengan komunikasi yang efektif, hubungan antar individu akan berkembang menjadi hubungan yang bermanfaat bagi diri sendiri maupun orang lain serta saling menguntungkan antar sesama individu.

\section{B. Pengertian Komunikasi Interpersonal}

Menurut Deddy Mulyana (2012:81) bahwa komunikasi antarpribadi (interpersonal communication) adalah komunikasi antara orang-orang secara tatap muka, yang memungkinkan setiap pesertanya menangkap reaksi orang lain secara langsung, baik secara verbal maupun nonverval. Bentuk khusus dari komunikasi antarpribadi ini adalah komunikasi diadik (dyadic communication) yang melibatkan hanya dua orang, seperti suami-isteri, dua sejawat, dua sahabat dekat, guru-murid, dan sebagainya. Ciri-ciri komunikasi diadik adalah pihak-pihak yang berkomunikasi berada dalam jarak dekat; pihak-pihak yang berkomunikasi mengirim dan menerima pesan secara simultan dan spontan, baik secara verbal atatupun nonverbal.

Menurut Arni (Muhammad 1989:12) pengertian komunikasi interpersonal adalah proses pertukaran informasi diantara seseorang dengan paling kurang seorang lainnya atau biasanya diantara dua orang yang dapat langsung diketahui balikannya. Dengan bertambahnya orang yang terlibat dalam komunikasi, menjadi bertambahlah persepsi orang dalam kejadian komunikasi sehingga bertambah kompleklah komunikasi Jenis komunikasi tersebut dianggap paling efektif untuk mengubah sikap, pendapat atau perilaku manusia

\footnotetext{
${ }^{11}$ Deddy Mulyana, 2008. Metode Penelitian Komunikasi. Bandung: Remaja Rosdakarya

${ }^{12}$ Ngalimun, 2017. Ilmu Komunikasi Sebuah Pengantar Praktis. Banjarmasin: Pustaka Banua
} 
berhubung prosesnya yang dialogis. Sifat dialogis itu ditunjukkan melalui komunikasi lisan dalam percakapan yang menampilkan arus balik yang langsung. Jadi komunikator mengetahui tanggapan komunikan pada saat itu juga, komunikator mengetahui dengan pasti apakah pesan-pesan yang ia kirimkan itu diterima atau ditolak, berdampak positif atau negatif. Jika tidak diterima maka komunikator akan memberi kesempatan yang seluas-luasnya

Jadi menurut beberapa pendapat di atas dapat disimpulkan pengertian komunikasi interpersonal adalah proses pertukaran informasi diantara seseorang dengan paling kurang seorang lainnya atau biasanya diantara dua orang yang dapat langsung diketahui balikannya. Dengan bertambahnya orang yang terlibat dalam komunikasi, menjadi bertambahlah persepsi orang lain dalam kejadian komunikasi sehingga bertambah kompleklah komunikasi tersebut. Komunikasi interpersonal adalah membentuk hubungan dengan orang lain.

Dari beberapa pengertian komunikasi interpersonal dan tenaga pendidik di atas maka dapat disimpulkan pengertian komunikasi interpersonal tenaga pendidik adalah proses pertukaran informasi antara seseorang yang mempunyai keahlian mengajar dan mendidik siswa dengan paling kurang seorang siswa yang dapat langsung diketahui balikannya untuk dapat menjadi seorang warga yang baik (susila), berilmu, produktif, sosial, sehat dan mampu berperan aktif dalam peningkatan sumber daya kemanusiaan.

\section{Model-Model komunikasi Interpersonal}

\section{1) Model Linier (Komunikasi Satu Arah)}

Komunikasi mengalir hanya dalam satu arah, yaitu dari pengirim ke penerima pasif. Dalam pembelajaran, pengirim yaitu wali kelas dan penerima yaitu siswa. Wali kelas hanya mengajar dengan metode ceramah. Ini berarti bahwa siswa tidak pernah mengirim pesan dan hanya menyerap secara pasif apa yang sedang dibicarakan. Siswa mengangguk, cemberut, tersenyum, tampak bosan atau tertarik, dan sebagainya.

Model linier juga keliru dengan mewakili komunikasi sebagai urutan tindakan dimana satu langkah (mendengarkan) mengikuti langkah sebelumnya (berbicara). Dalam interaksi yang sebenarnia, bagaimanapun, berbicara dan mendengarkan sering terjadi secara bersamaan atau mereka tumpang tindih. ${ }^{13}$

Setiap saat dalam proses komunikasi interpersonal, peserta secara bersamaan mengirim dan menerima pesan dan beradaptasi satu sama lain. (Julia T. Wood, 2010: 16)

\section{2) Model Interaktif (Komunikasi Dua Arah)}

Komunikasi sebagai sebuah proses dimana pendengar memberikan umpan balik, yang merupakan tanggapan terhadap pesan. Dalam pembelajaran, siswa memberikan umpan balik/tanggapan terhadap pesan yang disampaikan wali kelas. Jadi, wali kelas dan siswa memiliki peran yang sama, sebagai pemberi dan penerima reaksi.

Meskipun model interaktif merupakan perbaikan atas model linier, model interaktif ini masih menggambarkan komunikasi sebagai proses yang berurutan dimana satu orang adalah pengirim dan yang lain adalah penerima. Pada kenyataannya, semua orang yang terlibat dalam komunikasi mengirim dan menerima pesan.

\footnotetext{
${ }^{13}$ Wood, Julia T. 2010. Interpersonal Communication: Everyday Encounter. Australia: Wadsworth
} 
Model Interaktif juga gagal untuk menangkap sifat dinamis dari komunikasi interpersonal bahwa cara berkomunikasi berubah dari waktu ke waktu. Misalnya, guru dan siswa berkomunikasi dengan lebih mudah dan efektif setelah bermingguminggu tidak bertemu karena libur sekolah. (Julia T. Wood, $2010: 17$ )

\section{3) Model Transaksional (Komunikasi Banyak Arah)}

Model transaksional komunikasi interpersonal menekankan dinamika komunikasi interpersonal dan peran ganda orang yang terlibat dalam proses tersebut. Dalam model transaksional ini tidak hanya melibatkan interaksi dinamis antara wali kelas dengan siswa, tetapi juga interaksi dinamis antarsiswa. Proses belajar mengarah pada proses pembelajaran yang mengembangkan kegiatan siswa yang optimal, sehingga mendorong siswa aktif.

Model transaksional juga menjelaskan bahwa komunikasi terjadi dalam sistem yang mempengaruhi apa dan bagaimana orang berkomunikasi dan apa makna yang diciptakan. Sistem-sistem, atau konteks, termasuk sistem bersama dari kedua komunikator (sekolah, kota, tempat kerja, agama, kelompok sosial, atau budaya) dan sistem pribadi setiap orang (keluarga, asosiasi agama, teman-teman). Akhirnya, kita harus menekankan bahwa model transaksional tidak melabeli satu orang sebagai pengirim dan orang lain sebagai penerima.

Sebaliknya, kedua orang didefinisikan sebagai komunikator yang berpartisipasi sama dan sering bersamaan dalam proses komunikasi. Ini berarti bahwa pada saat tertentu dalam komunikasi, Anda dapat mengirim pesan (berbicara atau menganggukkan kepala), menerima pesan, atau melakukan keduanya pada saat yang sama (menafsirkan apa yang dikatakan seseorang ketika noding untuk menunjukkan Anda tertarik). (Julia T. Wood, $2010: 18)^{14}$

\section{Klasifikasi komunikasi interpersonal tenaga pendidik}

\section{1) Interaksi intim}

Interaksi intim termasuk komunikasi di antara tenaga pendidik dengan siswa. Di dalam sekolah, hubungan ini dikembangkan dalam system komunikasi informal. Misalnya: hubungan yang terlihat diantara tenaga pendidik dan siswa, yang mempunyai interaksi personal mungkin diluar peranan dan fungsinya dalam organisasi.

\section{2) Percakapan sosial}

Percakapan sosial adalah interaksi untuk menyenangkan seseorang secara sederhana dengan sedikit berbicara. Percakapan biasanya tidak begitu terlibat secara mendalam. Tipe komunikasi tatap muka penting bagi pengembangan hubungan informal dalam organisasi. Jika dua orang atau lebih bersama-sama dan berbicara tentang perhatian, minat diluar organisasi seperti famili, sport, isu politik, ini adalah merupakan contoh percakapan sosial.

\section{3) Interogasi atau pemeriksaan}

Interogasi atau pemeriksaan adalah interaksi antara seseorang yang ada dalam kontrol, yang meminta atau bahkan menurut informasi daripada yang lain. Misalnya

\footnotetext{
${ }^{14}$ Wood, Julia T. 2010. Interpersonal Communication: Everyday Encounter. Australia: Wadsworth
} 
seorang tenaga pendidik menanyai siswa yang datang terlambat. Perdebatan dan pertengkaran secara verbal adalah bentuk interogasi dimana kedua pihak menuntut satu sama lain dan kontrol sebentar-bentar bertukar. Pertengkaran verbal sering ditandai dengan isu benar atau salah. Debat diatur oleh sejumlah aturan dan umumnya lebih formal daripada perkelahian. Meskipun bentuk komunikasi ini tidaklah selalu diingini tetapi ada dalam organisasi. Misalnya: bila seseorang siswa dituduh memecahkan kaca ruangan kepala sekolah maka biasanya siswa tersebut diinterogasi oleh tenaga pendidik untuk mengetahui benar atau tidaknya tuduhan itu.

\section{4) Wawancara}

Wawancara adalah satu bentuk komunikasi interpersonal dimana dua orang terlibat dalam percakapan yang berupa tanya jawab. Salah seorang mengajukan pertanyaan untuk mendapatkan informasi dan yang lainnya mendengarkan dengan baik kemudian memberikan jawaban yang dikehendaki sampai tujuan wawancara tercapai. Misalnya seorang tenaga pendidik menanyai siswanya untuk mendapatkan informasi yang lebih jauh mengenai siswa tersebut. (Liliweri 1991) ${ }^{15}$

\section{E. Hubungan interpersonal yang efektif}

Menurut Rogert dalam bukunya Lunandi (1995) hubungan interpersonal akan terjadi secara efektif apabila kedua pihak memenuhi kondisi berikut: ${ }^{16}$

1) Bertemu satu sama lain secara personal

2) Empati secara tepat terhadap pribadi yang lain dan berkomunikasi yang dapat dipahami satu sama lain secara berarti

3) Menghargai satu sama lain, bersifat positif dan wajar tanpa menilai atau keberatan

4) Menghayati pengalaman satu sama lain dengan sungguh-sungguhnya, bersikap menerima dan empati satu sama lain

5) Merasa bahwa saling menjaga keterbukaan dan iklim yang mendukung dan mengurangi kecenderungan gangguan arti

6) Memperlihatkan tingkah laku yang percaya penuh dan memperkuat perasaan aman terhadap yang lain.

Adapun ciri-ciri komunikasi interpersonal yang efektif menurut Liliweri (1991:13) yakni: ${ }^{17}$

a. Komunikasi interpersonal biasanya terjadi secara spontan dan sambil lalu

b. Komunikasi interpersonal tidak mempunyai tujuan terlebih dahulu

c. Komunikasi interpersonal terjadi secara kebetulan di antara peserta yang tidak mempunyai identitas yang jelas.

d. Komunikasi interpersonal mempunyuai akibat yang disengaja maupun yang tidak disengaja

e. Komunikasi interpersonal seringkali berlangsung berbalas-balasan

f. Komunikasi interpersonal menghendaki paling sedikit melibatkan hubungan dua orang

\footnotetext{
${ }^{15}$ Liliweri Alo, 1991. Komunikasi Antar Pribadi. Bandung: Citra Aditya Bakti

${ }^{16}$ Lunandi, 1995. Komunikasi Mengena: Meningkatkan Efektivitas Komunikasi Antar Pribadi. Yogyakarta: Kamisius

${ }^{17}$ Liliweri Alo, 1991. Komunikasi Antar Pribadi. Bandung: Citra Aditya Bakti
} 
dengan suasana yang bebas, bervariasi, adanya keterpengaruhan komunikasi antar pribadi diakatakan tidak sukses jika tidak membuahkan hasil

g. Komunikasi antar pribadi menggunakan lambang-lambang bermakna

\section{F. Faktor Pendukung dan Penghambat Komunikasi}

Komunikasi interpersonal dipengaruhi oleh bebrapa faktor yang dapat mendukung atau malah menghambat keberhasilan komunikasi interpersonal tersebut. Faktor pendukung dan penghambat komunikasi interpersonal diuraikan sebagai berikut: ${ }^{18}$

1) Faktor Pendukung

Ada beberapa faktor yang mendukung keberhasilan komunikasi dilihat dari sudut komunikator, komunikan, dan pesan, sebagai berikut:

a) Komunikator memiliki kredibilitas/kewibawaan yang tinggi, daya tarik fisik maupun nonfisik yang mengundang simpati, cerdas dalam menganalisis suatu kondisi, memiliki integritas/keterpaduan antara ucapan dan tindakan, dapat dipercaya, mampu memahami situasi di lingkungan kerja, mampu mengendalikan emosi, memahami kondisi psikologis komunikan, bersikap supel, ramah, dan tegas, serta mampu menyesuaikan diri dengan masyarakat dimana ia berbicara.

b) Komunikan memiliki pengetahuan yang luas, memiliki kecerdasan menerima dan mencerna pesan, bersikap ramah, supel, dan pandai bergaul, memahami dengan siapa iaberbicara, bersikap bersahabat dengan komunikator.

c) Pesan komunikasi dirancang dan disampaikan sedemikian rupa, disampaikan secara jelas sesuai kondisi dan situasi, lambang-lambang yang digunakan dapat dipahami oleh komunikator dan komunikan, dan tidak menimbulkan multi interpretasi/penafsiran yang berlainan.

2) Faktor Penghambat

Faktor-faktor yang dapat menghambat komunikasi adalah sebagai berikut:

a) Komunikator komunikator gagap (hambatan biologis), komunikator tidak kredibel/tidak berwibawa dan kurang memahami karakteristik komunikan (tingkat pendidikan, usia, jenis kelamin, dan lain-lain) atau komunikator yang gugup (hambatan psikologis), perempuan tidak bersedia terbuka terhadap lawan bicaranya yang laki-laki (hambatan gender).

b) Komunikan yang mengalami gangguan pendengaran (hambatan biologis), komunikan yang tidak berkonsentrasi dengan pembicaraan (hambatan psikologis), seorang perempuan akan tersipu malu jika membicarakan masalah seksual dengan seorang lelaki (hambatan gender).

c) Komunikator dan komunikan kurang memahami latar belakang sosial budaya yang berlaku sehingga dapat melahirkan perbedaan persepsi.

d) Komunikator dan komunikan saling berprasangka buruk yang dapat mendorong ke arah sikap apatis dan penolakan.

e) Komunikasi berjalan satu arah dari komunikator ke komunikan secara terus menerus sehingga komunikan tidak memiki kesempatan meminta penjelasan.

f) Komunikasi hanya berupa penjelasan verbal/kata-kata sehingga membosankan.

\footnotetext{
${ }^{18}$ Effendi, Onong Uchjana. 2004. Dinamika Komunikasi. Bandung: Remaja Rosdakarya.
} 
g) Tidak digunakannya media yang tepat atau terdapat masalah pada teknologi komunikasi (microphone, telepon, power point, dan lain sebagainya).

h) Perbedaan bahasa sehingga menyebabkan perbedaan penafsiran pada simbolsimbol tertentu. ${ }^{19}$

\section{G. Pengertian Tenaga Pendidik}

A. Samana (1994:5) mengemukakan bahwa "tenaga pendidik adalah pribadi dewasa yang mempersiapkan diri secara khusus melalui lembaga pendidikan tenaga pendidik, agar dengan keahliannya mampu mengajar sekaligus mendidik siswanya untuk dapat menjadi warga negara yang baik (susila), berilmu, produktif, sosial, sehat dan mampu berperan aktif dalam peningkatan sumber daya manusia atau investasi kemanusiaan. ${ }^{20}$

Pada tahun 2003, depdiknas mengeluarkan Undang-Undang Republik Indonesia No. 20 tahun 2003 tentang Sistem Pendidikan Nasional pada pasal 3 UU RI No. Tahun 2003 tentang SISDIKNAS memuat pengertian" tenaga pendidik adalah anggota masyarakat yang mengabdikan diri dan diangkat untuk menunjang penyelenggaraan pendidikan.”

Dengan demikian dapat disimpulkan bahwa tenaga pendidik adalah seseorang yang mempunyai pribadi dewasa yang untuk menjadi tenaga pendidik mereka mempersiapkan diri melalui lembaga pendidikan ketenagapendidikan, sehingga mereka mempunyai keahlian mengajar dan mendidik siswa untuk dapat menjadi seorang yang warga baik (susila), berilmu, produktif, sosial, sehat dan mampu berperan aktif dalam peningkatan sumber daya kemanusiaan.

\section{H. Hasil Belajar}

Menurut Syaiful Bahri Djamarah "Belajar adalah serangkaian kegiatan jiwa dan raga untuk memperoleh suatu perubahan tingkah laku sebagai hasil dari pengalaman individu dalam interaksi dengan lingkungannya yang menyangkut kognitif, afektif dan psikomotorik". (Syaiful Bahri Djamarah, 2010:141) ${ }^{21}$

Menurut Slameto "Belajar adalah suatu proses perubahan, yaitu perubahan tingkah laku sebagai hasil interaksi dengan lingkungannya dalam memenuhi kebutuhan hidupnya". (Slameto, 2003:2) ${ }^{22}$

Dari pengertian belajar yang dikemukakan di atas terdapat beberapa perumusan yang berbeda satu sama lainnya. Tetapi secara umum dapat disimpulkan bahwa belajar adalah proses perubahan tingkah laku pada diri seseorang sebagai hasil dari interaksi dengan lingkungannya sehingga menimbulkan pengetahuan.

Perubahan tingkah laku yang terjadi itu sebagai akibat dari kegiatan belajar yang telah dilakukan individu. ${ }^{23}$ Perubahan itu berupa hasil yang telah dicapai dari proses belajar. Karena belajar adalah suatu proses, maka dari proses tersebut akan menghasilkan suatu hasil dan hasil dari proses belajar adalah berupa hasil belajar.

\footnotetext{
${ }^{19}$ Rosadi Ruslan, 2010. Metode Penelitian Public Relation dan Komunikasi. Jakarta: Rajawali Pers

${ }^{20}$ Samana A, 1994. Profesionalisme Ketenaga pendidikan. Yogyakarta: Kanisius

${ }^{21}$ Djamarah, Saiful Bahri, 2010. Guru dan anak Didik. Jakarta: Rineka Cipta

22 Slameto, 1995. Belajar dan Faktor-faktor Yang Mempengaruhinya. Jakarta: Rineka Cipta

${ }^{23}$ Ngalim Purwanto, 1990. Psikologi Pendidikan. Bandung: Renaja Rosdakarya
} 


\section{Pembahasan Hasil Penelitian}

Analisis Regresi adalah suatu cara atau teknik untuk mencari hubungan antara variabel satu dengan variabel lain yang dinyatakan dalam bentuk persamaan matematik dalam hubungan yang fungsional. Dalam pengertian lain, analisis regresi ingin mencari hubungan dari dua variabel atau lebih dengan mana variabel yang satu tergantung pada variabel yang lain.

Pada penelitian ini Analisa regresi ini gunakan untuk mengetahui apakah ada pengaruh Komunikasi Interpersonal Tenaga Pendidik (X 1), Kegiatan Belajar Mengajar ( $\mathrm{X} 2$ ), Fasilitas Belajar (X 3) dan Keberhasilan Belajar Siswa ( Y ) ${ }^{24}$

Uji Hipotesis :

Dengan uji $\mathrm{t}=$ untuk pengaruh parsial

Dengan uji $\mathrm{F}=$ untuk pengaruh parsial

$Y=a+b X_{1}+b X_{2}+b X_{3}$

Keterangan :

$\mathrm{Y}=$ Variabel terikat Keberhasilan Belajar Siswa

$\mathrm{X}_{1}=$ Variabel bebas Komunikasi Interpersonal Tenaga Pendidik

$\mathrm{X}_{2}=$ Variabel bebas Kegiatan Belajar Mengajar

$\mathrm{X}_{3}=$ Variabel bebas Fasilitas Belajar

$\mathrm{b}=$ koefisien regresi

a $=$ konstanta

Tabel. Model Summary

\begin{tabular}{|l|r|r|r|r|}
\hline Model & \multicolumn{1}{|c|}{$\mathrm{R}$} & R Square & \multicolumn{1}{c|}{$\begin{array}{c}\text { Adjusted R } \\
\text { Square }\end{array}$} & $\begin{array}{l}\text { Std. Error of } \\
\text { the Estimate }\end{array}$ \\
\hline 1 & $.471^{\mathrm{a}}$ & .222 & .163 & 2.269 \\
\hline
\end{tabular}

a. Predictors: (Constant), $\mathrm{x} 3, \mathrm{x} 1, \mathrm{x} 2$

Berdasarkan output di atas, dapat diketahui beberapa nilai antara lain : nilai koefosien regresi, thitung, nilai signifikansi, niai Fhitung, Nilai R Square atau R2.

Diperoleh nilai $\mathrm{R}=0,471$, dan nilai $\mathrm{R}$ Square $=0,222$ atau 22,2 \% di dalam model regresi variabel terikat Keberhasilan Belajar Siswa (Y) oleh varibel bebas yaitu Variabel bebas Komunikasi Interpersonal Tenaga Pendidik (X1), Variabel bebas Kegiatan Belajar Mengajar (X2), dan Variabel bebas Fasilitas Belajar (X3), secara bersama-sama sisanya $77,8 \%$ dijelaskan oleh faktor lain yang tidak diperhitungkan.

\footnotetext{
${ }^{24}$ Arikunto, 2006. Prosedur Penelitian Suatu Pendekatan Praktis. Jakarta: Rineka Cipta
} 
Table. Coefficients ${ }^{\mathrm{a}}$

\begin{tabular}{|c|c|c|c|c|c|c|}
\hline \multirow{2}{*}{\multicolumn{2}{|c|}{ Model }} & \multicolumn{2}{|c|}{$\begin{array}{l}\text { Unstandardized } \\
\text { Coefficients }\end{array}$} & \multirow{2}{*}{$\begin{array}{c}\text { Standardized } \\
\text { Coefficients }\end{array}$} & \multirow[b]{2}{*}{$\mathrm{T}$} & \multirow[b]{2}{*}{ Sig. } \\
\hline & & B & Std. Error & & & \\
\hline \multirow[t]{4}{*}{1} & (Constant) & -.251 & 7.370 & & -.034 & .973 \\
\hline & $\mathrm{x} 1$ & .355 & .271 & .190 & 1.310 & .198 \\
\hline & $\mathrm{x} 2$ & .014 & .332 & .007 & .043 & .966 \\
\hline & $\mathrm{x} 3$ & .500 & .195 & .433 & 2.567 & .014 \\
\hline
\end{tabular}

a. Dependent Variable: y

Dari tabel diatas diperoleh persamaan regresi:

$\mathrm{Y}=\mathrm{a}+\mathrm{bX} 1+\mathrm{bX} 2+\mathrm{bX} 3$

$\mathrm{Y}=-.251+0,355+0,014+0,500$

a. karena nilai t hitung dari varibel bebas Komunikasi Interpersonal Tenaga Pendidik X1 $=1.310$ lebih besar dari t tabel maka keputusan yang diambil adalah terdapat pengaruh signifikan Komunikasi Interpersonal Tenaga Pendidik dengan siswa Terhadap Hasil Belajar Madrasah Ibtidaiyah Assalam Martapura dan Madrasah Ibtidaiyah Negeri Sungai Sipai Martapura.

b. karena nilai t hitung dari varibel bebas Variabel bebas Kegiatan Belajar Mengajar X2 $=0.043$ lebih besar dari t tabel maka keputusan yang diambil adalah terdapat pengaruh parsial yang signifikan antara kegiatan belajar mengajar terhadap Keberhasilan Belajar Siswa Madrasah Ibtidaiyah Assalam Martapura dan Madrasah Ibtidaiyah Negeri Sungai Sipai Martapura.

c. karena nilai t hitung dari varibel bebas Fasilitas Belajar X3 $=2.567$ lebih besar dari $\mathrm{t}$ tabel maka keputusan yang diambil adalah terdapat pengaruh parsial yang signifikan fasilitas terhadap Keberhasilan Belajar Siswa Madrasah Ibtidaiyah Assalam Martapura dan Madrasah Ibtidaiyah Negeri Sungai Sipai Martapura.

\begin{tabular}{|c|c|c|c|c|c|c|}
\hline \multicolumn{7}{|c|}{ ANOVA $^{b}$} \\
\hline \multicolumn{2}{|c|}{ Model } & $\begin{array}{l}\text { Sum of } \\
\text { Squares }\end{array}$ & $\mathrm{df}$ & Mean Square & $\mathrm{F}$ & Sig. \\
\hline 1 & Regression & 58.709 & 3 & 19.570 & 3.800 & $.017^{\mathrm{a}}$ \\
\hline & Residual & 206.018 & 40 & 5.150 & & \\
\hline & Total & 264.727 & 43 & & & \\
\hline
\end{tabular}

a. Predictors: (Constant), x3, x1, x2

b. Dependent Variable: y 
Dari tabel ANOVA diperoleh hasil bahwa F hitung $=3.800$ dengan sig $=0,017$. Dapat disimpulkan bahwa, terdapat pengaruh simultan Komunikasi Interpersonal Antar Tenaga Pendidik dan Fasilitas Belajar secara terhadap Keberhasilan Belajar Siswa Madrasah Ibtidaiyah Assalam Martapura dan Madrasah Ibtidaiyah Negeri Sungai Sipai Martapura.

Beradasarkan output di atas, dapat diketahui beberapa nilai antara lain: nilai koefosien

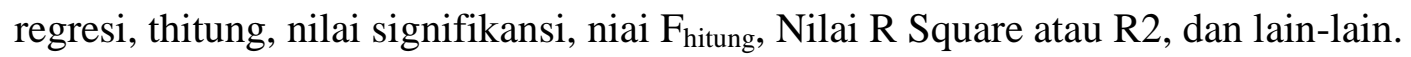

Tabel ringkasan

\begin{tabular}{|c|c|c|c|}
\hline Varibel & Koefesien regresi & $\mathrm{t}_{\text {hitung }}$ & Signifikansi \\
\hline Konstanta & -.251 & -.034 & 0.973 \\
\hline $\mathrm{X} 1$ & 0.355 & 1.310 & 0.198 \\
\hline $\mathrm{X} 2$ & 0.014 & 0.043 & 0.996 \\
\hline $\mathrm{X} 3$ & 0.500 & 2.567 & 0.014 \\
\hline $\begin{array}{l}\text { Nilai F } \\
\text { Nitung, }=3.800\end{array}$ & & \\
\hline
\end{tabular}

\section{KESIMPULAN}

Berdasarkan analisis data dan pembahasannya maka dapat dibuat simpulan penelitian sebagai berikut:

1. Terdapat pengaruh signifikan Komunikasi Interpersonal Tenaga Pendidik dengan siswa terhadap hasil belajar pada Madrasah Ibtidaiyah Assalam Martapura dan Madrasah Ibtidaiyah Negeri Sungai Sipai Martapura.

2. Terdapat pengaruh signifikan antara kegiatan belajar mengajar terhadap Keberhasilan Belajar Siswa Madrasah Ibtidaiyah Assalam Martapura dan Madrasah Ibtidaiyah Negeri Sungai Sipai Martapura

\section{DAFTAR PUSTAKA}

Arikuntoro, 2006. Prosedur Penelitian Suatu Pendekatan Praktik. Jakarta: Renika Cipta. AM. Sardiman, 2001. Interaksi dan Motivasi Belajar Mengajar. Jakarta: Raja Grafindo. Djamarah, Syaiful Bahri. 2010. Guru dan Anak Didik. Jakarta: Reneka Cipta. Effendi, Onong Uchjana. 2004. Dinamika Komunikasi. Bandung: Remaja Rosdakarya. Liliweri Alo. 1991. Komunikasi antar pribadi. Bandung: Citra Aditya Bakti.

Lunandi, 1995. Komunikasi Mengena: Meningkatkan Efektivitas Komunikasi Antar Pribadi. Yogyakarta: Kanisius.

Mulyana, Deddy, 2008. Metode Penelitian Komunikasi. Bandung: Remaja Rosdakarya. Ngalimun, 2017. Ilmu Komunikasi Sebuah Pengatar Praktis. Banjarmasin: Pustaka Banua. Ngalim Purwanto.1990. Psikologi pendidikan. Bandung: Remaja Rosdakarya.

Rosady Ruslan. 2010. Metode Penelitian Public Relation dan Komunikasi. Jakarta: Rajawali Pers.

Rachmat Kriyantono. 2010. Teknik Praktis Komunikasi. Jakarta: Kencana Prenada Media Group.

Piet. A, Sahertian. 1994. Profil Pendidik Profesional. Yogyakarta: Andi Offdit.

Samana, A. 1994. Profesionalisme Ketenaga pendidikan. Yogyakarta: Kanisius.

Slameto, 1995. Belajar dan Faktor-Faktor Yang Mempengaruhinya. Jakarta: Rineka Cipta. 
Jurnal NALAR Vol 1, No 2, Desember 2017

Suciati, 2015. Komunikasi Interpersonal. Yogyakarta: Buku Litera

Suranto Aw. 2010. Komunikasi Sosial Budaya. Yogyakarta: Graha Ilmu

Wood, Julia T. 2010. Interpersonal Communication: Everyday Encounters. Australia: Wadsworth. 